\title{
Effects of mandibular protraction appliance associated to fixed appliance in adults
}

\author{
Bruno D'Aurea Furquim¹, José Fernando Castanha Henriques², Guilherme Janson², \\ Danilo Furquim Siqueira3 ${ }^{3}$ Laurindo Zanco Furquim ${ }^{4}$
}

Objective: This retrospective study aimed to conduct a cephalometric evaluation of the skeletal, dental and soft tissue effects resulting from treatment of adult patients presenting Class II malocclusion, performed with a Mandibular Protraction Appliance (MPA) combined with a fixed orthodontic appliance. Methods: The sample consisted of teleradiographs obtained before and after treatment of 9 adult patients (initial mean age of 22.48 years) with bilateral Class II, division 1, malocclusion. Paired $t$ test $(\mathrm{p}<0.05)$ was applied to compare initial and final values. Results: $t$ test revealed an increase in anteroinferior facial height and posterior facial height. The dental changes include: extrusion of upper incisors, buccal inclination, protrusion of lower incisors, mesialization and extrusion of mandibular molars. Regarding the soft tissue component, there was an increase in nasolabial angle in addition to upper lip retrusion. Conclusions: The effects of treating Class II malocclusion adult patients, by means of using Mandibular Protraction Appliance (MPA) combined with a fixed appliance were mostly observed in the mandibular arch, and consisted of buccal inclination, protrusion and intrusion of incisors, and mesialization and extrusion of the molars.

Keywords: Angle Class II Malocclusion. Functional orthodontic appliances. Mandibular advancement. Adult.

Objetivo: esse estudo retrospectivo teve como objetivo avaliar, cefalometricamente, os efeitos esqueléticos, dentários e tegumentares decorrentes do tratamento com o Aparelho de Protração Mandibular em conjunto ao aparelho fixo em pacientes adultos para correção da má oclusão de Classe II. Métodos: a amostra foi composta por telerradiografias prée pós-tratamento de nove adultos (idade inicial média de 22,48 anos), portadores de má oclusão de Classe II, divisão 1 bilateral. O teste $t$ pareado $(\mathrm{p}<0,05)$ foi empregado para comparação dos valores iniciais e finais. Resultados: de acordo com o teste $t$, observou-se aumento da altura facial anteroinferior e da altura facial posterior. As alterações dentárias foram: extrusão dos incisivos superiores, inclinação para vestibular e protrusão dos incisivos inferiores; e mesialização e extrusão dos molares inferiores. Com relação ao componente tegumentar, houve aumento do ângulo nasolabial e retrusão do lábio superior. Conclusão: os efeitos do tratamento com o Aparelho de Protração Mandibular em conjunto com aparelho fixo em pacientes adultos para correção da má oclusão de Classe II foram direcionados, principalmente, à arcada inferior, com inclinação vestibular, protrusão e intrusão dos incisivos e mesialização e extrusão dos molares.

Palavras-chave: Má oclusão Classe II de Angle. Aparelhos ortodônticos funcionais. Avanço mandibular. Adulto.

${ }^{1} \mathrm{PhD}$ Student in Oral Rehabilitation, School of Dentistry of Bauru, University of São Paulo (FOB-USP).

${ }^{2}$ Full and Head Professor, University of São Paulo (USP).

${ }^{3} \mathrm{PhD}$ in Orthodontics, FOB-USP. Professor, UNICID.

${ }^{4} \mathrm{PhD}$ in Oral Pathology, FOB-USP. Associate Professor, State University of Maringá (UEM).
How to cite this article: Furquim BD, Henriques JFC, Janson G, Siqueira DF, Furquim LZ. Effects of mandibular protraction appliance associated to fixed appliance in adults. Dental Press J Orthod. 2013 Sept-Oct;18(5):46-52.

Submitted: November 24, 2009 - Revised and accepted: December 29, 2010

" The authors report no commercial, proprietary or financial interest in the products or companies described in this article.

Contact address: Bruno D’Aurea Furquim

Rua Arthur Thomas, 999 - Maringá/PR - CEP: 87013-250 - Brazil

Email: brunofurquim@hotmail.com 


\section{INTRODUCTION}

Treatment of adult patients has become a reality in orthodontic practice for many years. ${ }^{1,2,3}$ For cases of adult patients with mandibular deficiency, two treatment approaches are usually available. The first is compensatory, involving premolar extractions, allowing retraction of upper incisors and, as a result, overjet correction, while the second is surgical, repositioning the mandible more anteriorly. ${ }^{4}$

In addition to these two more traditional treatment options, functional fixed appliances constitute yet a third alternative to treat Class II malocclusion without extraction or surgery. ${ }^{4-12}$

The Herbst appliance was the first fixed functional appliance designed for the correction of Class II malocclusion, and also the first one described for this purpose in adult patients. ${ }^{8}$ Besides the Herbst appliance, there are other fixed functional appliances effective in the correction of Class II malocclusion such as the Jasper Jumper, the MARA, the AMF and MPA. ${ }^{5,6,7,13}$ The Mandibular Protraction Appliance (MPA) stands out for its easy fabrication, low cost and swift installation. ${ }^{14}$

Some studies have compared the treatment of Class II malocclusion with MPA associated to other appliances in adolescent patients. ${ }^{13,15}$ Clinical cases of adult patients treated with MPA can be found in the literature. ${ }^{16,17,18}$ But no research has yet been conducted to investigate treatment with MPA in a group of adult patients. Thus, this retrospective study aimed to conduct a cephalometric evaluation of the skeletal, dental and soft tissue effects resulting from treatment with MPA in combination with fixed appliance in adult patients presenting with Class II malocclusion.

\section{MATERIAL AND METHODS}

In selecting the sample, the following inclusion criteria were applied:

1. Presence of early bilateral Class II, division 1, malocclusion.

2. Absence of agenesis and no permanent teeth missing.

3. Absence of supernumerary teeth.

4. Treatment conducted exclusively with MPA combined with a fixed orthodontic appliance.

5. Class I molar relationship with a reduced overjet at the end of treatment.
Patients were defined as adults based on the cervical vertebral maturation method for evaluation of mandibular growth proposed by Baccetti et al. ${ }^{21} \mathrm{~Pa}-$ tients in the fifth cervical vertebral maturation stage (CVMS V) and above were considered adults. Evaluation was performed using the initial teleradiograph. Patients who raised any doubt as to their classification were excluded from the sample.

The sample consisted of nine Brazilian Caucasian adults ( 6 females and 3 males) presenting bilateral Class II division 1 malocclusion. The patients had an initial mean age of 22.48 years (S.D. $=5.64$, ranging from 15.14 to 29.69 years.) The mean follow-up period was 4.01 years, and the final mean age of the patients was 26.50 years. The patients were treated by experienced professors.

As this was a retrospective study, the teleradiographs were taken at different centers. The anatomical tracing and landmarks were scanned on a flatbed Numonics AccuGrid XNT, model A30TL.F (Austin, Texas/ USA). Dentofacial Planner 7.02 software (Toronto, Ontario - Canada) was used for measuring the cephalometric variables since this computer program automatically corrects the radiographic image magnification. Midplane tracing was performed on bilateral structures, except for the molars, given that the more distally positioned molar was used as reference.

Intraexaminer error was determined by taking new measurements of 15 teleradiographs, either initial or final, after an interval of 30 days since the first measurement. Systematic errors were analyzed by dependent test as described by Houston. ${ }^{19}$

For evaluation of casual errors the Dahlberg test was utilized, which shows the average change between the first and second measurements. The test is performed by the formula $S^{2}=\Sigma d^{2} / 2 n$, where $S^{2}$ is the error variance, $d$ represents the difference between the first and second measurement, and $\mathrm{n}$ is the number of measurement pairs. ${ }^{20}$ Random error was calculated using a Microsoft Excel XP spreadsheet.

Kolmogorov-Smirnov test was used to assess if the values had a normal distribution, thus allowing the dependent $t$ test to be performed. The latter was performed to compare the mean cephalometric values at the beginning and end of treatment.

Statistical tests were carried out using Statistica software. Results where $p<0.05$ were considered to be statistically significant. 


\section{RESULTS}

Only two variables (1-PTV and 1-PP) exhibited systematic error approximately one month after the first measurement, and random errors ranged from 0.28 for SML to 2.80 for 1.PP (Table 1).

MPA revealed no significant changes in the maxilla or mandible. As regards growth pattern, only the linear variables (anteroinferior facial height and posterior facial height) changed.

Incisor extrusion was the only significant change noted in the maxillary dentoalveolar component. On the other hand, the mandibular dentoalveolar component showed buccal inclination, incisor protrusion, and molar mesialization and extrusion. The treatment achieved significant correction of overjet and overbite as well as molar relationship. Regarding the soft tissue component, the nasolabial angle increased and the upper lip retracted relative to line E.

\section{DISCUSSION}

This study evaluated the dental, skeletal and soft tissue effects of correcting Class II malocclusion in a group of adult patients using Mandibular Protraction Appliances (MPAs). The Cervical Vertebral Maturation Method for assessment of mandibular growth, ${ }^{21}$ and the patient's chronological age were the criteria used to classify patients as adults. Given that no other researcher has ever evaluated the effects of MPA on adult patients, the results will be compared with those of other studies that evaluated fixed functional appliances other than MPAs for correction of Class II malocclusion in adults or young adults .

It is noteworthy that the effects observed in this study result from treatment carried out with MPAs and fixed appliances. Further studies are warranted to evaluate not only the overall effects of treatment, but also specific effects observed in the period when the MPA was in place.

\section{Skeletal effects}

Other studies are in agreement with the results in terms of MPA effects on the maxilla. Treatment with MPA in a group with initial mean age of 15 years and five months was also unable to produce effects in the maxilla. ${ }^{6}$ Nalbantgil et $\mathrm{al}^{7}$ assessed the effects of Jasper Jumper in a group with an initial mean age of 16.5 years, and reported it had limited effects on the maxilla. Moreover, no significant differences were found between the beginning and end of treatment. However, in comparison with the control group, the authors suggested that Jasper Jumper inhibited the growth potential of the maxilla.

As in the present study, Nalbantgil et $\mathrm{al}^{7}$ observed no significant effects on mandibular growth in patients with an initial mean age of 16.5 years treated with Jasper Jumper. However, significant changes were observed in the maxillomandibular relationship. Gönner et $\mathrm{al}^{5}$ observed greater reduction (3 degrees) in the ANB angle, and in older patients (33.7 years ( SD 7.9) treated with MARA.

With regard to growth pattern, only the linear variables (anteroinferior facial height and posterior facial height) increased, which can also be construed as a result of late changes in craniofacial growth. Nalbantgil et $\mathrm{a}^{7}$ also observed no changes in the growth pattern. Ruf and Pancherz $^{12}$ observed that the SN.GoGn angle did not change during the Herbst phase, which is consistent with studies of Herbst in children. Decreases in the SN.GoGn angle during the fixed appliance phase and throughout the observation period as well as mandibular advancement caused a reduction in the convexity of the skeletal and soft tissue profile. The opposite seems to have occurred with controls, of which convexity increased over time.

\section{Dental effects}

In agreement with the present study, Nalbantgil et $\mathrm{al}^{7}$ noted extrusion in upper incisors as a result of treatment with Jasper Jumper. They also observed retraction of the upper incisors and distal tipping of the molar crown, which was not observed in this study. This may have been due to the fact that patients in this study were older (22.41 years) than patients evaluated by Nalbantgil et $\mathrm{al}^{7}$ (16.5 years.) Given that the lower lip droops with aging, ${ }^{22}$ extrusion of upper incisors can be regarded as an advantage afforded by this treatment.

The lower dentoalveolar component exhibited significant changes in nearly all variables (buccal inclination, incisor protrusion and intrusion, mesialization and extrusion of molars), except for the vertical position of the incisors as these remained unchanged.

Ruf and Pancherz ${ }^{11}$ showed the dental and facial adjustments they achieved in adolescents and young adults. In both groups, Class II and overjet correction 
Table 1 - Results of paired t test and Dahlberg's formula applied to variables studied to estimate random and systematic errors, respectively.

\begin{tabular}{|c|c|c|c|c|c|}
\hline \multirow{2}{*}{ VARIABLES } & 1st measurement & 2nd measurement & \multirow{2}{*}{$\begin{array}{c}\text { Difference } \\
\text { between means }\end{array}$} & \multirow{2}{*}{ Dahlberg } & \multirow{2}{*}{$\mathbf{p}$} \\
\hline & Mean \pm SD & Mean \pm SD & & & \\
\hline \multicolumn{6}{|c|}{ Maxillary Component } \\
\hline SNA (degrees) & $80.19 \pm 4.28$ & $80.77 \pm 4.85$ & 0.57 & 1.93 & 0.435 \\
\hline A-Nperp (mm) & $2.40 \pm 4.12$ & $1.53 \pm 4.37$ & -0.87 & 1.84 & 0.207 \\
\hline Co-A (mm) & $85.93 \pm 3.61$ & $86.45 \pm 4.00$ & 0.52 & 0.90 & 0.118 \\
\hline \multicolumn{6}{|c|}{ Mandibular Component } \\
\hline SNB (degrees) & $76.23 \pm 4.12$ & $76.85 \pm 4.52$ & 0.61 & 1.26 & 0.193 \\
\hline Pog-Nperp (mm) & $0 \pm 5.91$ & $-1.28 \pm 6.29$ & -1.28 & 1.96 & 0.072 \\
\hline Co-Gn (mm) & $108.21 \pm 5.73$ & $108.15 \pm 5.75$ & -0.06 & 0.79 & 0.844 \\
\hline Go-Gn (mm) & $72.86 \pm 4.96$ & $73.58 \pm 5.02$ & 0.72 & 1.87 & 0.308 \\
\hline Co-Go (mm) & $53.21 \pm 6.51$ & $52.09 \pm 6.16$ & -1.12 & 2.22 & 0.175 \\
\hline \multicolumn{6}{|c|}{ Maxillomandibular relationship } \\
\hline ANB (degrees) & $3.97 \pm 2.48$ & $3.92 \pm 2.30$ & -0.05 & 0.90 & 0.893 \\
\hline NAP (degrees) & $4.44 \pm 6.74$ & $4.14 \pm 6.18$ & -0.30 & 1.17 & 0.501 \\
\hline Co-A/Co-Gn (mm) & $79.47 \pm 2.11$ & $79.99 \pm 1.77$ & 0.51 & 0.93 & 0.137 \\
\hline \multicolumn{6}{|c|}{ Growth pattern } \\
\hline FMA (degrees) & $20.09 \pm 7.74$ & $21.21 \pm 7.19$ & 1.12 & 2.17 & 0.165 \\
\hline SN.GoGn (degrees) & $29.28 \pm 9.13$ & $28.58 \pm 8.84$ & -0.70 & 1.91 & 0.334 \\
\hline SN.PP (degrees) & $7.75 \pm 5.62$ & $8.14 \pm 4.59$ & 0.39 & 1.73 & 0.559 \\
\hline AlFH (mm) & $63.39 \pm 3.73$ & $62.63 \pm 3.55$ & -0.76 & 1.54 & 0.184 \\
\hline $\mathrm{S}-\mathrm{GO}(\mathrm{mm})$ & $74.97 \pm 7.81$ & $74.55 \pm 7.81$ & -0.43 & 1.10 & 0.306 \\
\hline \multicolumn{6}{|c|}{ Maxillary dentoalveolar component } \\
\hline 1.PP (degrees) & $101.93 \pm 9.72$ & $106.75 \pm 5.74$ & 4.82 & 2.80 & 0.150 \\
\hline 1-PP (mm) & $28.26 \pm 1.90$ & $27.49 \pm 2.01$ & -0.77 & 0.98 & $0.024^{*}$ \\
\hline 1.NA (graus) & $15.81 \pm 9.34$ & $17.86 \pm 8.94$ & 2.05 & 2.21 & 0.085 \\
\hline 1-NA (mm) & $2.77 \pm 3.26$ & $3.17 \pm 3.21$ & 0.40 & 1.03 & 0.304 \\
\hline 1-PTV & $56.10 \pm 5.01$ & $55.28 \pm 5.90$ & -0.82 & 1.17 & 0.050 \\
\hline 6-PP (mm) & $22.54 \pm 1.27$ & $22.47 \pm 1.23$ & -0.07 & 0.47 & 0.682 \\
\hline 6-PTV & $27.34 \pm 4.21$ & $26.33 \pm 4.32$ & -1.01 & 1.75 & 0.116 \\
\hline \multicolumn{6}{|c|}{ Mandibular dentoalveolar component } \\
\hline IMPA (degrees) & $102.81 \pm 6.60$ & $102.71 \pm 5.85$ & -0.10 & 1.54 & 0.892 \\
\hline 1.NB (degrees) & $31.39 \pm 7.06$ & $31.59 \pm 6.18$ & 0.21 & 1.50 & 0.720 \\
\hline 1-NB (mm) & $4.95 \pm 2.21$ & $4.74 \pm 2.41$ & -0.21 & 0.79 & 0.479 \\
\hline 1-PM (mm) & $38.09 \pm 2.19$ & $38.11 \pm 2.38$ & 0.02 & 1.54 & 0.973 \\
\hline 1-PTV & $52.62 \pm 4.80$ & $51.59 \pm 5.74$ & -1.03 & 1.28 & $0.021^{*}$ \\
\hline 6-PM (mm) & $29.86 \pm 2.49$ & $29.84 \pm 2.72$ & -0.02 & 1.17 & 0.964 \\
\hline 6-PTV & $28.25 \pm 4.45$ & $27.31 \pm 4.75$ & -0.94 & 1.67 & 0.126 \\
\hline \multicolumn{6}{|c|}{ Dental relationships } \\
\hline T.H. $(m m)$ & $3.48 \pm 0.74$ & $3.69 \pm 0.65$ & 0.21 & 0.45 & 0.221 \\
\hline T.V. (mm) & $3.33 \pm 0.97$ & $3.02 \pm 1.21$ & -0.31 & 0.42 & 0.221 \\
\hline Molar relationship & $-0.91 \pm 1.65$ & $-0.99 \pm 1.62$ & -0.07 & 0.30 & 0.520 \\
\hline \multicolumn{6}{|c|}{ Soft tissue component } \\
\hline ANL & $111.29 \pm 6.65$ & $111.41 \pm 5.52$ & 0.12 & 2.88 & 0.914 \\
\hline SML & $6.03 \pm 0.97$ & $6.02 \pm 0.84$ & -0.01 & 0.28 & 0.950 \\
\hline UL-E & $-4.21 \pm 1.96$ & $-4.14 \pm 1.91$ & 0.07 & 1.38 & 0.900 \\
\hline LL-E & $-2.09 \pm 2.91$ & $-1.81 \pm 2.70$ & 0.28 & 1.68 & 0.663 \\
\hline UL-Pog'Sn & $2.70 \pm 1.14$ & $2.92 \pm 1.23$ & 0.22 & 0.83 & 0.486 \\
\hline LL-Pog'Sn & $1.41 \pm 2.42$ & $1.67 \pm 2.22$ & 0.26 & 1.26 & 0.588 \\
\hline
\end{tabular}


Table 2 - Comparison between initial and final mean values by paired $t$ test.

\begin{tabular}{|c|c|c|c|c|}
\hline \multirow{2}{*}{ VARIABLES } & Initial $(n=9)$ & Final $(n=9)$ & \multirow{2}{*}{$\begin{array}{c}\text { Difference } \\
\text { between means }\end{array}$} & \multirow{2}{*}{$\mathbf{p}$} \\
\hline & Mean \pm SD & Mean \pm SD & & \\
\hline \multicolumn{5}{|c|}{ Chronological age } \\
\hline Age & $22.48 \pm 5.64$ & $26.50 \pm 6.32$ & 4.01 & $0.000^{*}$ \\
\hline \multicolumn{5}{|c|}{ Maxillary component } \\
\hline SNA (degrees) & $79.83 \pm 6.52$ & $80.24 \pm 6.87$ & 0.41 & 0.255 \\
\hline A-Nperp (mm) & $-0.54 \pm 3.29$ & $0.07 \pm 4.16$ & 0.61 & 0.215 \\
\hline Co-A (mm) & $85.01 \pm 8.06$ & $85.20 \pm 7.77$ & 0.19 & 0.537 \\
\hline \multicolumn{5}{|c|}{ Mandibular component } \\
\hline SNB (degrees) & $76.70 \pm 6.44$ & $77.13 \pm 5.93$ & 0.43 & 0.279 \\
\hline Pog-Nperp (mm) & $-3.28 \pm 5.38$ & $-1.92 \pm 5.47$ & 1.36 & 0.169 \\
\hline Co-Gn (mm) & $109.82 \pm 8.34$ & $110.38 \pm 7.74$ & 0.56 & 0.219 \\
\hline Go-Gn (mm) & $73.43 \pm 4.75$ & $73.90 \pm 4.92$ & 0.47 & 0.110 \\
\hline Co-Go (mm) & $53.07 \pm 7.85$ & $53.49 \pm 7.00$ & 0.42 & 0.407 \\
\hline \multicolumn{5}{|c|}{ Maxillomandibular relationship } \\
\hline ANB (degrees) & $3.14 \pm 2.57$ & $3.12 \pm 3.20$ & -0.02 & 0.959 \\
\hline NAP (degrees) & $2.38 \pm 6.94$ & $2.33 \pm 8.04$ & -0.04 & 0.957 \\
\hline Co-A/Co-Gn (mm) & $77.41 \pm 4.22$ & $77.19 \pm 4.30$ & -0.22 & 0.422 \\
\hline \multicolumn{5}{|c|}{ Growthpattern } \\
\hline FMA (degrees) & $23.18 \pm 7.73$ & $22.76 \pm 7.75$ & -0.42 & 0.378 \\
\hline SN.GoGn (degrees) & $30.41 \pm 11.13$ & $30.06 \pm 10.53$ & -0.36 & 0.439 \\
\hline SN.PP (degrees) & $7.64 \pm 5.44$ & $7.02 \pm 5.36$ & -0.62 & 0.271 \\
\hline AlFH (mm) & $63.18 \pm 6.17$ & $64.86 \pm 5.36$ & 1.68 & $0.010^{*}$ \\
\hline $\mathrm{S}-\mathrm{GO}(\mathrm{mm})$ & $74.14 \pm 10.19$ & $75.58 \pm 9.50$ & 1.43 & $0.011^{*}$ \\
\hline \multicolumn{5}{|c|}{ Maxillary dentoalveolar component } \\
\hline 1.PP (degrees) & $114.51 \pm 9.65$ & $111.23 \pm 5.94$ & -3.28 & 0.192 \\
\hline 1-PP $(\mathrm{mm})$ & $26.71 \pm 3.13$ & $28.22 \pm 3.00$ & 1.51 & $0.027^{*}$ \\
\hline 1.NA (degrees) & $27.06 \pm 12.10$ & $23.94 \pm 8.98$ & -3.11 & 0.220 \\
\hline 1-NA (mm) & $6.41 \pm 4.24$ & $4.79 \pm 3.71$ & -1.62 & 0.064 \\
\hline 1-PTV & $57.21 \pm 4.25$ & $56.54 \pm 5.30$ & -0.67 & 0.441 \\
\hline 6-PP $(\mathrm{mm})$ & $22.69 \pm 2.48$ & $23.03 \pm 2.37$ & 0.34 & 0.339 \\
\hline 6-PTV & $27.07 \pm 3.34$ & $27.36 \pm 4.19$ & 0.29 & 0.809 \\
\hline \multicolumn{5}{|c|}{ Mandibular dentoalveolar component } \\
\hline IMPA (degrees) & $99.62 \pm 4.77$ & $105.37 \pm 4.53$ & 5.74 & $0.000^{*}$ \\
\hline 1.NB (degrees) & $29.14 \pm 4.94$ & $35.13 \pm 4.48$ & 5.99 & $0.000 *$ \\
\hline $1-\mathrm{NB}(\mathrm{mm})$ & $4.93 \pm 2.41$ & $5.78 \pm 2.02$ & 0.84 & $0.023^{*}$ \\
\hline 1-PM (mm) & $39.10 \pm 3.31$ & $38.16 \pm 2.92$ & -0.94 & 0.124 \\
\hline 1-PTV & $51.59 \pm 5.36$ & $53.32 \pm 4.96$ & 1.73 & $0.053^{*}$ \\
\hline 6-PM (mm) & $28.59 \pm 3.56$ & $30.87 \pm 2.84$ & 2.28 & $0.001^{*}$ \\
\hline 6-PTV & $26.63 \pm 4.35$ & $29.72 \pm 4.13$ & -3.09 & $0.027^{*}$ \\
\hline \multicolumn{5}{|c|}{ Dental relationships } \\
\hline T.H. (mm) & $5.62 \pm 2.76$ & $3.22 \pm 0.57$ & -2.40 & $0.035^{*}$ \\
\hline T.V. (mm) & $3.08 \pm 1.75$ & $1.48 \pm 1.24$ & -1.60 & $0.008^{*}$ \\
\hline Molar relationship & $0.43 \pm 2.06$ & $-2.06 \pm 0.30$ & -2.49 & $0.007^{*}$ \\
\hline \multicolumn{5}{|c|}{ Soft tissue component } \\
\hline ANL & $108.19 \pm 11.05$ & $109.32 \pm 12.46$ & 1.13 & $0.007^{*}$ \\
\hline SML & $6.34 \pm 1.22$ & $6.12 \pm 1.34$ & -0.22 & 0.548 \\
\hline UL-E & $-3.36 \pm 2.38$ & $-4.36 \pm 1.94$ & -1.00 & $0.006^{*}$ \\
\hline LL-E & $-2.08 \pm 2.84$ & $-2.13 \pm 2.42$ & -0.06 & 0.888 \\
\hline UL-Pog'Sn & $3.27 \pm 1.91$ & $2.94 \pm 1.77$ & -0.32 & 0.365 \\
\hline LL-Pog'Sn & $1.37 \pm 2.53$ & $1.68 \pm 2.04$ & 0.31 & 0.539 \\
\hline
\end{tabular}

${ }^{*} p<0.05$ 
was promoted mostly by dental changes and to a lesser extent by skeletal changes. ${ }^{10}$ Adolescent patients showed greater mandibular growth, whereas young adult patients exhibited greater molar mesialization and consequently greater protrusion of the lower incisors. Gönner et $\mathrm{al}^{5}$ observed an increase of more than $5^{\circ}$ in the IMPA of adult patients (33.7 years) treated with MARA combined with fixed appliances. Conversely, Nalbantgil et $\mathrm{al}^{7}$ observed - in addition to lower incisor protrusion - intrusion of these same teeth, as was the case in the present study.

Buccal inclination of lower incisors and its impact on periodontal status is controversial. Some studies have seen protrusion as a risk factor for gingival recession since an association between recession and buccal movement has been observed. ${ }^{22-25}$ Others did not note such association. ${ }^{26,27,28}$ To Melsen and Allais, ${ }^{29}$ other predisposing factors for gingival recession should be taken into account such as gingival biotype, visible plaque and inflammation.

A positive relationship between the patient's age and the severity of bone loss has been identified. ${ }^{30,31}$ According to Ko-Kimura et $\mathrm{al},{ }^{32}$ the prevalence of black spaces in post-orthodontic treatment is greater in patients over twenty years old, and these spaces are linked to resorption of the alveolar crest. The average prevalence of black spaces found in the adult orthodontic population post-treatment, regardless of the initial crowding, was 38\%,,$^{33}$ and $43 \%$ in adolescents after correction of incisor crowding, according to Burke. ${ }^{34}$ Tanaka et $\mathrm{al}^{35}$ demonstrated that due to crowding the interdental papilla can be crushed and it is only after the dental malocclusions have been corrected that black space may become evident. Tuverson ${ }^{36}$ reported that since triangular teeth have no contact areas, but rather contact points, these teeth are more unstable and more susceptible to crowding. According to Olsson and Lindhe, ${ }^{37}$ patients with triangular maxillary central incisors (slender and tall) tend to develop more gingival recession than those patients with wider and shorter maxillary central incisors, since there seems to be a relationship between "gingival biotype" and shape of the upper central incisor.

How maxillary incisors are positioned determines to a great extent the motivation that drives adult patients to seek orthodontic treatment. Few of these patients even notice skeletal abnormalities. ${ }^{38}$ Therefore, preventive care should be provided for as long as there is orthodontic movement, mainly protrusive movement, in patients with thin gum / triangular incisor "biotype." Special attention should be paid when these features are associated with some degree of crowding and/or visible plaque and inflammation.

\section{Soft tissue effects}

Retrusion of the upper lip in terms of variable LL-E and an increased nasolabial angle were observed. These changes may have been influenced by nose growth, since the upper lip remained unchanged in terms of variable UL-Pog'Sn, consistent with the unchanged position of upper incisors in the sagittal direction. Despite the fact that protrusion and labial inclination of the lower incisors did occur, the lower lip did not protrude.

\section{CONCLUSIONS}

The effects of treating Class II malocclusion in adults using a Mandibular Protraction Appliance combined with fixed orthodontic appliance were mostly observed in the mandibular arch, and consisted of buccal inclination, incisor protrusion, and mesialization and extrusion of the molars. Incisor extrusion was the only significant change observed in the maxillary arch. 
1. Harris EF, Vaden JL, Dunn KL, Behrents RG. Effects of patient age on postorthodontic stability in Class II, division 1 malocclusions. Am J Orthod Dentofacial Orthop. 1994:105(1):25-34.

2. Kokich $V$, Mathews $D$. Managing treatment for the orthodontic patient with periodontal problems. Semin Orthod. 1997;3(1):21-38.

3. LaSota E. Orthodontic considerations in prosthetic and restorative dentistry. Dent Clin North Am. 1988;32(3):447-56.

4. Ruf S, Pancherz H. Orthognathic surgery and dentofacial orthopedics in adult Class II division 1 treatment: mandibular sagittal split osteotomy versus Herbst appliance. Am J Orthod Dentofacial Orthop. 2004;126(2):140-52; quiz 254-5.

5. Gonner U, Ozkan V, Jahn E, Toll DE. Effect of the MARA appliance on the position of the lower anteriors in children, adolescents and adults with Class II malocclusion. J Orofac Orthop. 2007:68(5):397-412.

6. Kinzinger G, Diedrich P. Skeletal effects in Class II treatment with the functional mandibular advancer (FMA)? J Orofac Orthop. 2005;66(6):469-90.

7. Nalbantgil D, Arun T, Sayinsu K, Fulya I. Skeletal, dental and soft-tissue changes induced by the Jasper Jumper appliance in late adolescence. Angle Orthod. 2005;75(3):426-36

8. Paulsen HU. Morphological changes of the TMJ condyles of 100 patients treated with the Herbst appliance in the period of puberty to adulthood: a long-term radiographic study. Eur J Orthod. 1997:19(6):657-68.

9. Paulsen HU, Karle A. Computer tomographic and radiographic changes in the temporomandibular joints of two young adults with occlusal asymmetry, treated with the Herbst appliance. Eur J Orthod. 2000:22(6):649-56.

10. Ruf S, Pancherz H. Dentoskeletal effects and facial profile changes in young adults treated with the Herbst appliance. Angle Orthod 1999:69(3):239-46.

11. Ruf S, Pancherz H. Temporomandibular joint remodeling in adolescents and young adults during Herbst treatment: a prospective longitudinal magnetic resonance imaging and cephalometric radiographic investigation. Am J Orthod Dentofacial Orthop. 1999;115(6):607-18

12. Ruf S, Pancherz H. Herbst/multibracket appliance treatment of Class II division 1 malocclusions in early and late adulthood. A prospective cephalometric study of consecutively treated subjects. Eur J Orthod. 2006:28(4):352-60. Epub 2006 Apr 27.

13. Siqueira D, de Almeira RR, Janson G, Brandão AG, Coelho Filho CM. Dentoskeletal and soft-tissue changes with cervical headgear and mandibular protraction appliance therapy in the treatment of Class II malocclusions. Am J Orthod. 2007:131(4):447.e 21-30.

14. Coelho Filho CM. Mandibular protraction appliances for Class II treatment. J Clin Orthod. 1995:29(5):319-36

15. Alves P, Oliveira A, Silveira C, Oliveira J, Oliveira Júnior J, Coelho Filho C Estudo comparativo dos efeitos esqueléticos, dentários e tegumentares, promovidos pelo tratamento da má oclusão Classe II mandibular com o aparelho de Herbst e com o Aparelho de Protração Mandibular. Rev Clín Ortod Dental Press. 2006:5(1):85-105

16. Bicalho J, Bicalho R. Utilização do APM no tratamento da má oclusão

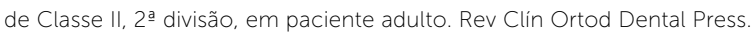
2007:6(1):99-106.

17. Coelho Filho C. Clinical application of the Mandibular Protraction Appliance in upper lateral agenesis and in asymmetric cases. Texas Dent J. 2002;119(7):618-26.

18. Coelho Filho C, White L. Treating adults with the Mandibular Protraction Appliance. Orthodontic Cyber J. 2003 jan [Access 2009 Jul 20]. Available from: http://orthocj.com/2003/01/treating-adults-with-the-mandibularprotraction-appliance/
19. Houston WJ. The analysis of errors in orthodontic measurements. Am J Orthod. 1983:83(5):382-90

20. Dahlberg G. Statistical methods for medical and biological students Br Med J. 1940:2(4158):358-9

21. Baccetti T, Franchi L, McNamara JA Jr. An improved version of the cervical vertebral maturation (CVM) method for the assessment of mandibular growth. Angle Orthod. 2002:72(4):316-23.

22. Dorfman HS. Mucogingival changes resulting from mandibular incisor tooth movement. Am J Orthod. 1978:74(3):286-97.

23. Fuhrmann R. Three-dimensional interpretation of labiolingual bone width of the lower incisors. Part II. J Orofac Orthop. 1996:57(3):168-85.

24. Hollender $L$, Ronnerman A, Thilander B. Root resorption, marginal bone support and clinical crown length in orthodontically treated patients. Eur J Orthod. 1980:2(4):197-205.

25. Wennstrom JL, Lindhe J, Sinclair F, Thilander B. Some periodontal tissue reactions to orthodontic tooth movement in monkeys. J Clin Periodontol. 1987:14(3):121-9.

26. Artun J, Krogstad $O$. Periodontal status of mandibular incisors following excessive proclination. A study in adults with surgically treated mandibular prognathism. Am J Orthod Dentofacial Orthop. 1987:91(3):225-32.

27. Djeu G, Hayes C, Zawaideh S. Correlation between mandibular central incisor proclination and gingival recession during fixed appliance therapy. Angle Orthod. 2002;72(3):238-45

28. Hansen $K$, Pancherz $H$, Petersson A. Long-term effects of the Herbst appliance on the craniomandibular system with special reference to the TMJ. Eur J Orthod. 1990:12(3):244-53.

29. Melsen B, Allais D. Factors of importance for the development of dehiscences during labial movement of mandibular incisors: a retrospective study of adult orthodontic patients. Am J Orthod Dentofacial Orthop. 2005;127(5):552-61; quiz 625.

30. Van der Geld P, Oosterveld P, Kuijpers-Jagtman AM. Age-related changes of the dental aesthetic zone at rest and during spontaneous smiling and speech. Eur J Orthod. 2008;30(4):366-73

31. Nelson PA, Artun J. Alveolar bone loss of maxillary anterior teeth in adult orthodontic patients. Am J Orthod Dentofacial Orthop. 1997:111(3):328-34

32. Ko-Kimura N, Kimura-Hayashi M, Yamaguchi M, Ikeda T, Meguro D, Kanekawa M, et al. Some factors associated with open gingival embrasures following orthodontic treatment. Aust Orthod J. 2003;19(1):19-24

33. Kurth JR, Kokich VG. Open gingival embrasures after orthodontic treatment in adults: prevalence and etiology. Am J Orthod Dentofacial Orthop. 2001:120(2):116-23.

34. Burke S, Burch JG, Tetz JA. Incidence and size of pretreatment overlap and posttreatment gingival embrasure space between maxillary central incisors. Am J Orthod Dentofacial Orthop. 1994:105(5):506-11.

35. Tanaka OM, Furquim BD, Pascotto RC, Ribeiro GL, Bosio JA, Maruo H. The dilemma of the open gingival embrasure between maxillary central incisors. J Contemp Dent Pract. 2008;9(6):92-8.

36. Tuverson DL. Anterior interocclusal relations. Part I. Am J Orthod. $1980 ; 78(4): 361-70$

37. Olsson $\mathrm{M}$, Lindhe J. Periodontal characteristics in individuals with varying form of the upper central incisors. J Clin Periodontol. 1991:18(1):78-82.

38. Maltagliati L, Montes $L$. Análise dos fatores que motivam os pacientes adultos a buscarem o tratamento ortodôntico. Rev Dental Press Ortod Ortop Facial. 2007:12(6):54-60. 